\title{
PROFILE USAHA PETERNAKAN BABI SKALA KECIL DI DESA PUHU KECAMATAN PAYANGAN KABUPATEN GIANYAR
}

\author{
SURANJAYA, I G., M. DEWANTARI, I K. W. PARIMARTHA, DAN I W. SUKANATA \\ Fakultas Peternakan, Universitas Udayana \\ email : suranjaya_gede@yahoo.co.id
}

\begin{abstract}
ABSTRAK
Penelitian ini dilakukan dengan tujuan untuk mengetahui profile atau keragaan dari usaha peternakan babi skala kecil yang dilakukan oleh peternak di Desa Puhu-Payangan. Metode survai digunakan dalam penelitian ini terhadap peternak babi skala kecil yang ada di desa Puhu-Payangan. Penentuan sampel dilakukan secara "purposive random sampling" sebanyak 50 orang peternak babi skala usaha kecil. Pendekatan eksploratif serta wawancara dengan responden dilakukan untuk mendeskripsikan profile peternak dan usaha peternakan itu. Data yang diperoleh dianalisis dan disajikan secara deskriptif. Hasil penelitian menunjukkan bahwa profile peternak pada usaha peternakan babi skala kecil di desa Puhu adalah tergolong berada pada usia produktif (76\%), memiliki tingkat pendidikan menengah (44\%), berpengalaman (92\%), melakukan usaha ini sebagai usaha produktif (80\%) dan aktif terlibat dalam kelompok ternak (70\%). Profile dari usaha peternakan ini adalah termasuk jenis usaha kombinasi penggemukan dan perbibitan, jumlah pemilikan ternak rata-rata 14,04 ekor atau 3,38 satuan ternak per peternak dengan status kepemilikan ternak 100\% milik sendiri. Usaha peternakan babi sangat diminati dan dapat menunjang ekonomi keluarga peternak. Secara ekonomi usaha ini memberi keuntungan secara rata-rata sebesar Rp. 5.232.700 per 1 kali periode produksi.
\end{abstract}

Kata kunci: profile, usaha peternakan babi, peternakan skala kecil

\section{THE PROFILE OF SMALL PIG FARMS AT PUHU VILLAGE DISTRICT OF PAYANGAN GIANYAR REGENCY}

\begin{abstract}
This research was conducted in order to determine the profile or the performance of small-scale pig farm carried out by farmers in the village of Puhu-Payangan. The survey method used in this research. The samples were carried out in a "purposive random sampling" as many as 50 small-scale pig farmers. Explorative approach as well as interviews with respondents was conducted to describe the profile of farmers and the farm it. Then the data were analyzed and presented descriptively. The results showed that the profile of farmers on a small scale pig farm in the village Puhu is classified as being in the productive age (76\%), have a level of secondary education (44\%), experienced (92\%), doing business as productive businesses (80\%) and actively engaged in livestock group (70\%). Profile of a farm is the kind of business combination of fattening and breeding, the number of livestock ownership on average 14.04 tail or 3.38 livestock units per livestock farmer with 100\% ownership of their own. Pig farm is in great demand and can support farming family economy. Economically, this business is profitable on average Rp. 5,232,700.00 per one time period of production.
\end{abstract}

Keywords: profile, a pig farm, small-scale farms

\section{PENDAHULUAN}

Prospek usaha pemeliharaan ternak babi di Bali saat ini cukup cerah, sejalan dengan pertumbuhan perekonomian serta berkembangnya sentra-sentra bisnis yang secara langsung maupun tak langsung mendorong meningkatnya permintaan terhadap daging babi. Daging babi adalah produk hasil ternak yang memiliki tingkat permintaan dan konsumen cukup besar di Bali (Disnak. Prop. Bali. 2012). Besarnya permintaan daging babi selain memang untuk pemenuhan konsumsi masyarakat, keberadaan dan peranan ternak babi juga cukup penting dalam kehidupan sosial dan tradisi masyarakat Bali. Kondisi seperti itu disamping merupakan tantangan sekaligus juga merupakan peluang bagi para peternak untuk mengembangkan usaha peternakan, melakukan jasa 
penyedia daging babi ataupun membuka usaha makanan siap saji seperti rumah makan dan warung makan khusus babi guling yang digemari oleh masyarakat.

Menurut Riady (2004) bahwa usaha budidaya ternak seperti usaha pemeliharaan babi yang dilakukan oleh sebagian besar masyarakat perdesaan saat ini adalah masih bersifat sambilan dengan skala usaha pemeliharaan rata-rata 10 ekor/peternak serta orientasinya untuk menghasilkan komoditas sesuai permintaan pasar juga masih rendah. Namun secara umum usaha pemeliharaan ternak seperti itu juga tetap diandalkan sebagai sumber pendapatan, penghasil daging, sebagai sumber lapangan kerja, pengguna limbah pertanian atau rumah tangga dan sebagai tabungan bagi masyarakat. Hadi dan Ilham (2002) menyebutkan bahwa usaha peternakan rakyat dapat dikatagorikan sebagai usaha perbibitan dan penggemukkan dengan jumlah pemilikan ternak terbatas. Sedangkan Sihombing (2006) menyatakan bahwa terdapat tiga katagori usaha ternak babi rakyat yaitu: usaha perbibitan, usaha penggemukan dan usaha kombinasi dari kedua kegiatan tersebut. Secara ekonomi usaha penggemukan akan memberikan keuntungan yang lebih besar, namun modal yang ditanamkan juga lebih besar dibanding usaha pembibitan. Akan tetapi integrasi selalu terjadi diantara kedua bentuk usaha tersebut, dimana usaha pembibitan adalah menghasilkan ternak bibit ataupun ternak bakalan sedangkan usaha penggemukan adalah sebagai pengguna ternak bakalan itu sendiri untuk memproduksi ternak potong.

Faktor- faktor karakteristik sosial ekonomi peternak seperti jumlah ternak, umur, tingkat pendidikan, lamanya beternak, jumlah tanggungan keluarga, dan jumlah tenaga kerja memiliki peran yang sangat penting di dalam suatu usaha pemeliharaan ternak. Karakteristik peternak tersebut nantinya akan membentuk pola pikir dari peternak dalam menangani proses budidaya ternaknya yang dapat mencerminkan keberhasilan usaha itu.

Berdasarkan kenyataan tersebut, penelitian ini dilakukan untuk mengungkapkan karakteristik dan profile keberadaan usaha peternakan babi rakyat atau skala kecil yang terdapat di Desa Puhu-Payangan Kabupaten Gianyar.

\section{MATERI DAN METODE}

\section{Materi}

Penelitian ini dilakukan dengan metode survey terhadap usaha peternak babi rakyat (skala rumah tangga) di desa Puhu-Payangan, Kabupaten Gianyar. Sebanyak 50 orang peternak babi ditetapkan sebagai sampel dalam penelitian ini. Pengambilan sampel dilakukan secara purposive random sampling, dengan pertimbangan bahwa peternak yang dijadikan sebagai sampel penelitian adalah peternak dengan jumlah pemilikan ternak paling banyak 30 ekor per peternak.

\section{Metode}

Metode wawancara dengan menggunakan daftar pertanyaan (kuisioner) dilakukan pada peternak babi skala kecil. Pengambilan data dilakukan di tiga lokasi yaitu banjar (dusun) Kebek, Ponggang dan Penginyahan dengan pertimbangan bahwa di tiga dusun itu keberadaan peternakan babi rakyat paling banyak jumlahnya. Pendekatan eksploratif digunakan untuk mengobservasi tentang keberadaan atau profile dari peternak, usaha peternakan babi dan karakter ekonomi dari usaha peternakan babi rakyat itu. Data yang dikumpulkan meliputi: karakteristik peternak, karakteristik usaha peternakan babi rakyat, karakteristik ekonomi usaha (nilai jual ternak, biaya produksi, nilai penjualan ternak, keuntungan usaha per 1 periode produksi). Informasi tambahan yang dibutuhkan diperoleh melalui observasi di lapangan atau wawancara dengan kelompok ternak dan aparat desa.

\section{Analisa Statistika}

Tabulasi dilakukan terhadap data primer dan sekunder, selanjutnya dianalisis secara deskriptif untuk menunjukkan keragaan atau profile peternak dan usaha peternakan tersebut. Untuk mengkaji profile ekonomi dari usaha peternakan babi rakyat itu dilakukan dengan menghitung pendapatan bersih peternak selama 1 periode produksi (6 bulan) yang diperoleh dari nilai penjualan ternak dikurangi total biaya produksi (Soekartawi, 2003), dengan rumus:

$$
\begin{aligned}
& \mathrm{NR}=\mathrm{TR}-\mathrm{TC} \\
& \mathrm{TR}=\text { Py.Y - (Px.X + TFC) } \\
& \text { Keterangan: }
\end{aligned}
$$

$\mathrm{NR}=$ pendapatan bersih, $\mathrm{TR}=$ pendapatan total, $\mathrm{TC}$ = biaya total, $\mathrm{X}=$ input, $\mathrm{Px}=$ harga input, $\mathrm{Y}=$ out put, $\mathrm{Py}$ $=$ harga out put, $\mathrm{TFC}=$ total biaya tetap.

\section{HASIL DAN PEMBAHASAN}

\section{Profile Peternak}

Kisaran umur peternak pada usaha peternakan babi skala kecil ini adalah $25-65$ tahun dengan rata-rata 45,96 tahun. Peternak yang berumur $25-55$ tahun yaitu sebanyak 38 orang (76\%), lebih dari 55 tahun sebanyak 12 orang (24\%). Secara umum usia peternak yang menjalankan usaha peternakan babi skala kecil di Desa Puhu masih tergolong berada pada kondisi usia produktif kerja (Tabel 1).

Tingkat pendidikan responden sangat bervariasi, yaitu 22 orang peternak berpendidikan SMA (44\%), 8 orang pendidikan SMP (16\%), 18 orang SD (36\%), dan 2 orang sarjana (4\%). Menurut Rachmat (2002) pendidikan akan 
mempengaruhi seseorang dalam menerima inovasi, semakin tinggi pendidikan, maka responden akan memiliki kemampuan yang semakin baik pula dalam mengadopsi inovasi. Latar belakang pendidikan formal serta tingkat pengetahuan responden adalah salah satu faktor penunjang untuk memahami pola pengembangan dan managemen usaha peternakan.

Sebagian besar responden sudah berumah tangga dengan jumlah anggota keluarga $2-8$ orang. Sebanyak $68 \%$ responden dengan jumlah keluarga 2-5 orang dan $32 \%$ dengan jumlah keluarga lebih dari 5 orang. Peternak dengan jumlah keluarga yang lebih banyak cenderung lebih giat menjalankan usahanya agar berhasil dan memperoleh keuntungan sehingga dapat digunakan untuk memenuhi kebutuhan keluarga. Jumlah tanggungan keluarga yang lebih banyak menjadi kendala tersendiri dalam upaya pengembangan usaha karena hasil usaha hampir selalu terserap digunakan untuk memenuhi keperluan rumah tangga, sehingga tidak ada kesempatan mengalokasikan dana itu untuk mengembangkan usaha lebih lanjut.

Tabel 1. Profile peternak usaha peternakan babi skala kecil di Desa Puhu

\begin{tabular}{lcc}
\hline \multicolumn{1}{c}{ Karakteristik Peternak } & \multicolumn{2}{c}{ Responden Peternak } \\
\cline { 2 - 3 } & Jumlah (orang) & Persentase \\
\hline Umur (tahun): & 38 & 76 \\
- 20 - 55 tahun & 12 & 24 \\
- Lebih dari 55 tahun & & \\
Pendidikan: & 18 & 36 \\
- SD & 8 & 16 \\
- SMP & 22 & 44 \\
- SMA & 2 & 4 \\
- Sarjana & & \\
Jumlah Anggota Keluarga & 34 & 68 \\
- 2 - 5 & 16 & 32 \\
- Lebih dari 5 & & \\
Pengalaman Beternak: & 4 & 8 \\
- 1 - 5 tahun & 46 & 92 \\
- Lebih dari 5 tahun & & \\
Alasan untuk beternak & 40 & 80 \\
- sebagai sumber pendapatan & 10 & 20 \\
- sebagai usaha sambilan & & \\
Keterlibatan dlm Kelompok Ternak & 35 & 30 \\
- Bergabung & 15 & \\
- Tidak bergabung & & \\
\hline
\end{tabular}

Sebagian besar responden termasuk peternak yang sudah berpengalaman, 92\% responden memiliki pengalaman beternak lebih dari 5 tahun dan sebanyak $8 \%$ kurang dari 5 tahun. Dengan pengalaman cukup lama serta jenjang pendidikan memadai, menyebabkan responden dapat menjalankan usahanya dengan baik. Pengalaman beternak adalah lamanya seseorang berkecimpung dalam usaha ternak itu, yang mempunyai pengalaman lebih lama cenderung lebih cepat dalam pengambilan keputusan karena pengalaman dapat dijadikan pedoman dalam melakukan usahanya.

Sebanyak 80\% responden menyatakan alasan beternak itu adalah sebagai sumber pendapatan dan $20 \%$ menyatakan sebagai usaha sambilan atau pengisi waktu luang. Sebagian besar responden cukup yakin bahwa usaha peternakan babi itu dapat menghasilkan uang/ dana untuk memenuhi kebutuhan ekonomi keluarga ataupun kepentingan sosial lainnya (upacara adat). Hal itu disebabkan karena ternak babi baik sebagai ternak potong ataupun ternak bibit memiliki prospek pasar yang sangat cerah. Menurut Disnak-Bali (2012) daging babi adalah produk hasil ternak yang memiliki tingkat permintaan dan jumlah konsumen cukup besar. Daging babi selain untuk memenuhi kebutuhan konsumsi daging bagi masyarakat umum, juga banyak dibutuhkan dalam upacara tradisi dan sosial di Bali.

Kebanyakan responden sudah tergabung di dalam wadah organisasi Kelompok Ternak, yaitu 70\% dari total responden terdaftar sebagai anggota kelompok dan sisanya 30\% belum atau tidak terdaftar. Keterlibatan di dalam wadah kelompok ternak sebenarnya bermanfaat bagi responden karena melalui kelompok biasanya dapat dilakukan saling tukar informasi tentang pengalaman beternak ataupun informasi tentang harga pasar.

\section{Profile Usaha Peternakan Babi Skala Kecil}

Usaha pemeliharaan babi skala kecil di Desa Puhu 90\% termasuk katagori usaha kombinasi yaitu gabungan antara usaha perbibitan dengan penggemukan. Apabila dari usaha perbibitan belum panen bibit namun peternak membutuhkan biaya untuk pemeliharaan ternak atau kepentingan lainnya maka peternak dapat menjual ternak potong babi dewasa dari usaha penggemukannya. Ataupun sebaliknya bila terjadi peningkatan kebutuhan ternak potong dan daging, maka bibit-bibit yang berkualitas baik yang dihasilkannya tidak akan dijual tetapi cenderung untuk dipelihara sebagai ternak potong. Strategi usaha itu dilakukan karena dirasakan lebih menguntungkan dan dapat diandalkan sebagai penunjang ekonomi keluarganya.

Status kepemilikan ternak dari responden adalah 100\% milik sendiri dengan kisaran pemilikan ternak $2-33$ ekor atau rata-rata $=14,04$ ekor per peternak atau setara dengan 3,38 satuan ternak (ST). Bangsa ternak babi yang dipelihara sebagian besar adalah babi Landrace. Rataan jumlah pemilikan ternak dari responden berdasarkan fase umur dalam satuan ternak dapat dilihat seperti pada Tabel 2. Untuk nilai satuan ternak babi ditetapkan sebagai berikut: 1). anak babi umur $<6$ bulan setara dengan o,1 ST, 2). babi muda umur 0,5 - 1 tahun setara dengan 0,2 ST, dan 3). babi dewasa umur $>1$ tahun setara dengan 0,4 ST. 
Tabel 2. Rataan pemilikan ternak berdasarkan fase umur dalam satuan ternak (ST)

\begin{tabular}{lccc}
\hline \multicolumn{1}{c}{ Jenis Ternak } & Fase Umur & Rataan (ekor) & ST \\
\hline Anak babi (kucit) & Starter & 6,28 & 0,628 \\
Babi muda (bakalan) & Grower & 1,72 & 0,344 \\
Babi dewasa (celeng) & Finisher & 2,88 & 1,152 \\
Betina dewasa (bangkung) & Induk & 3,16 & 1,264 \\
Jumlah & & 14,04 & 3,38 \\
\hline
\end{tabular}

Seluruh responden menggunakan tenaga kerja keluarga yaitu berkisar 1-3 orang, dengan tenaga kerja utamanya adalah laki-laki dewasa (bapak) dibantu oleh wanita dewasa (istri) dan anak dengan kapasitas kerja berkisar 1-2,08 dengan lama waktu kerja 0,5 - 1 jam per hari. Terkait dengan kegiatan pengelolaan usahanya, responden lebih mengandalkan bapak (laki-laki) sebagai pekerja utamanya dan para isteri hanya membantu saja, kecuali untuk masalah dalam menerima hasil penjualan ternak sebagian besar dilakukan oleh para istri. Tidak terdapat penggunaan tenaga kerja luar keluarga pada usaha pemeliharaan babi skala kecil di Desa Puhu ini.

\section{Performa Biaya Produksi}

Biaya produksi untuk 1 kali periode produksi (6 bulan) secara rata-rata adalah Rp. 13.948.500. Komposisi biaya produksi terdiri dari biaya tidak tetap (variabel) dan biaya tetap ( $f(x)$ masing-masing sebesar $94 \%$ dan 6\% dari total biaya produksi. Zadrak et al. (2014) melaporkan bahwa biaya tidak tetap dan biaya tetap masing-masing sebesar $75,58 \%$ dan $24,46 \%$ dari total biaya produksi yang digunakan dalam proses produksi pada usaha peternakan babi "Kasawean" di Tomohon. Sementara Simon Pardede (2015) mendapatkan biaya tidak tetap yang digunakan untuk proses produksi oleh usaha peternakan babi rakyat di desa Cigugur-Kuningan Jawa Barat yaitu sebesar 97,13\% dari total biaya produksi.

Biaya variabel atau biaya tidak tetap adalah biaya yang dikeluarkan atau ditanggung oleh peternak selama 1 periode produksi yang besar kecilnya dipengaruhi oleh skala atau jumlah produksi. Semakin tinggi skala produksi maka akan semakin meningkat pula biaya variabel yang harus ditanggung oleh peternak. Hal ini sesuai dengan pendapat Soekartawi (2003), bahwa biaya variabel adalah biaya yang berubah-ubah mengikuti besar kecilnya volume produksi, seperti pengeluaran untuk sarana produksi, biaya pengadaan bibit, obatobatan, pakan dan lain sebagainya. Biaya tidak tetap dengan persentase paling besar pada penelitian ini adalah berasal dari biaya pakan yaitu mencapai $67,60 \%$ dari total biaya produksi. Aritonang (2010) menyatakan bahwa biaya pakan merupakan biaya terbesar pada usaha pemeliharaan ternak yaitu bisa mencapai antara 60-80\% dari keseluruhan biaya produksi. Sementara hasil penelitian Hardyastuti (2011) menunjukkan bahwa biaya pakan yang dikeluarkan oleh peternak pada suatu
Tabel 3. Komposisi rata-rata biaya produksi (Rp/Unit Usaha/Periode).

\begin{tabular}{|c|c|c|c|c|}
\hline \multirow{2}{*}{ Komponen Biaya } & Nyata & Tersamar & Jumlah & Persen \\
\hline & \multicolumn{3}{|c|}{ 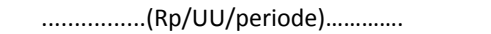 } & (\%) \\
\hline \multicolumn{5}{|l|}{ Biaya tetap: } \\
\hline - Sewa lahan & & $209.227,50$ & $209.227,50$ & 1,50 \\
\hline - Penyusutan kandang. & $418.455,00$ & & 418 & 3,00 \\
\hline - Peny & 139.4 & & $139.485,00$ & 1,00 \\
\hline - Upakara Tern & $69.742,50$ & & $69.742,50$ & 0,50 \\
\hline Total biaya tetap & $627.682,50$ & $209.227,50$ & $836.910,00$ & 6,00 \\
\hline \multicolumn{5}{|l|}{ Biaya tidak tetap: } \\
\hline - Bibit & $1.241 .416,50$ & & $1.241 .416,50$ & 8,90 \\
\hline - Pakan & 9.429 & & 9.429 & 67,60 \\
\hline - Obat & & & & 2,25 \\
\hline - Sewa P & $606.759,75$ & & $606.759,75$ & 4,35 \\
\hline - Tenaga Kerja & & $1.394 .850,00$ & $1.394 .850,00$ & 10,00 \\
\hline - Listrik \& air & $125.536,50$ & & $125.536,50$ & 0,9 \\
\hline Total biaya tidak tetap & $11.716 .740,00$ & $1.394 .850,00$ & $13.111 .590,00$ & 94,00 \\
\hline Total biaya produksi & $12.344 .422,50$ & $1.604 .077,50$ & $13.948 .500,00$ & 100,00 \\
\hline
\end{tabular}

untuk pemeliharaan ternak babi berkisar antara 70-80\% dari keseluruhan biaya produksi.

\section{Performa Penerimaan Usaha}

Performa penerimaan terdiri atas hasil penjualan dari anak babi, babi muda, babi dewasa dan induk afkir. Rata-rata jumlah penerimaan dari hasil penjualan ternak selama 1 periode produksi (6 bulan) ditampilkan seperti pada Tabel 4 .

Tabel 4. Rata-rata penerimaan berdasarkan rata-rata jumlah dan fase ternak yang terjual selama 1 periode.

\begin{tabular}{lrrrr}
\hline No. $\quad$ Fase Ternak & $\begin{array}{c}\text { Rataan } \\
\text { berat } \\
(\mathrm{kg})\end{array}$ & $\begin{array}{c}\text { Rata-rata } \\
\text { jumlah } \\
\text { (ekor) }\end{array}$ & \multicolumn{1}{c}{$\begin{array}{c}\text { Harga } \\
(\mathrm{Rp})\end{array}$} & \multicolumn{1}{c}{$\begin{array}{c}\text { Jumlah } \\
(\mathrm{Rp})\end{array}$} \\
\hline 1 Anak/kucit (starter) & 15 & 10,6 & $550000 /$ ekor & 5830000 \\
2 Babi muda (grower) & 50 & 1,72 & $23000 / \mathrm{kg}$ & 1978000 \\
3 Babi dewasa/Celeng & 110 & 2,88 & $24000 / \mathrm{kg}$ & 8294400 \\
$\quad$ (finisher) & & & & \\
4 Induk /bangkung (afkir) & 150 & 1,42 & $18000 / \mathrm{kg}$ & 3078800 \\
& Jumlah & & & 19181200 \\
\hline
\end{tabular}

Dari Tabel 4 nampak bahwa rata-rata jumlah penerimaan peternak responden pada penelitian ini selama 1 periode produksi masing-masing berasal dari hasil penjualan anak babi sebesar 31,03\%, babi muda 8,42\%; babi dewasa sebesar 44,17\% dan penjualan induk afkir (bangkung) sebesar $16,38 \%$. Persentase penerimaan terbesar berasal dari hasil penjualan babi dewasa atau celeng dan selanjutnya disusul oleh penjualan anak babi. Hal ini disebabkan karena babi dewasa adalah babi fase finisher dari proses penggemukan dan umumnya digunakan sebagai penghasil daging untuk memenuhi kebutuhan masyarakat, restoran, hotel dan beberapa usaha lainnya. Prospek pasar untuk daging babi cukup besar di Bali dan kebutuhannya semakin meningkat pada musim kegiatan adat istiadat dan sosial masyarakat serta musim puncak kedatangan wisatawan ke Bali. Sementara kebutuhan terhadap anak babi dan babi muda juga cukup tinggi di Bali, disamping digunakan sebagai ternak bibit untuk dikembangkan lebih lanjut juga dibutuhkan un- 
tuk pembuatan "babi guling" sebagai sarana pelengkap upacara agama dan juga untuk kuliner yang sangat digemari oleh masyarakat. Zadrak et al. (2014) melaporkan bahwa pada usaha peternakan babi rakyat di Tomohon penjualan ternak fase strarter dilakukan karena ternak fase starter akan dijadikan bibit oleh para pembeli peternak babi yang ada di luar Kota Tomohon. Penjualan ternak babi starter juga dirasakan lebih baik karena dapat menghindari biaya operasional seperti biaya pakan yang cenderung berfluktuasi karena harga pakan yang sering tidak stabil.

\section{Performa Keuntungan}

Besarnya pendapatan atau keuntungan yang diperoleh dihitung berdasarkan selisih dari total penerimaan nilai penjualan ternak dikurangi dengan total biaya yang dikeluarkan. Jumlah penerimaan yang diperoleh dari hasil penjualan ternak babi dengan skala usaha 3,38 ST selama satu periode produksi (6 bulan) rata-rata sebesar Rp. 19.181.200,oo. Sementara total biaya produksi yang dikeluarkan rata-rata sebesar Rp.13.948.500,00, sehingga diperoleh keuntungan usaha secara rata-rata sebesar Rp. 5.232.700,o0 per 1 kali periode produksi. Pendapatan atau keuntungan dipengaruhi oleh penjualan ternak, dimana nilai dari penjualan ditentukan oleh jumlah kepemilikan ternak yang dipelihara. Pada skala usaha dengan kepemilikan ternak induk lebih banyak akan mampu menghasilkan anak yang lebih banyak pula sehingga menghasilkan nilai penjualan yang lebih besar. Besarnya pendapatan yang dihasilkan dipengaruhi oleh jumlah kepemilikian ternak. Hal ini sesuai dengan pendapat (Soekartawi, 2003), pendapatan usaha ternak sangat dipengaruhi oleh banyaknya ternak yang dijual oleh peternak itu sendiri sehingga semakin banyak jumlah ternak yang terjual maka semakin tinggi pula pendapatan bersih yang diperoleh.

\section{SIMPULAN}

Dari hasil penelitian ini dapat disimpulkan bahwa profile peternak pada usaha pemeliharaan babi skala kecil di Desa Puhu adalah tergolong sebagai tenaga kerja usia produktif, memiliki motivasi yang baik dengan tingkat pendidikan menengah serta memiliki alasan bahwa usaha pemeliharaan babi sebagai usaha produktif untuk menunjang ekonomi keluarga. Profile usaha peternakan babi skala kecil di Desa Puhu-Payangan adalah usaha yang dapat memberikan keuntungan secara ekonomi serta mampu diandalkan sebagai usaha penunjang ekonomi keluarga peternak sehingga cukup menarik minat masyarakat desa Puhu untuk menekuni usaha ini.

\section{UCAPAN TERIMA KASIH}

Penulis mengucapkan terima kasih kepada Bapak Rektor Universitas Udayana, Dekan Fakultas Peternakan serta Ketua LPPM Universitas Udayana atas bantuan dana serta fasilitas yang diberikan sehingga penelitian dapat terlaksana dengan baik. Ucapan terima kasih juga disampaikan kepada para peternak responden di Banjar Ponggang dan Banjar Penginyahan Desa Puhu-Payangan atas bantuan dan kerjasamanya yang baik.

\section{DAFTAR PUSTAKA}

Aritonang., 2010. Beternak Babi "Perencanaan dan Pengelolaan Usaha”. Edisi Revisi. Penebar Swadaya. Jakarta.

Disnak. Prop. Bali. 2012. Informasi Data Peternakan 2011. Dinas Peternakan dan Kesehatan Hewan Propinsi Bali.

Hadi, P.U., dan N. Ilham. 2002. Problem dan prospek pengembangan usaha pembibitan sapi potong di Indonesia. Jurnal Litbang Pertanian. Vol 21(4). Badan Litbang Pertanian. Dep. Pertanian-Jakarta.

Hardyastuti, 2011. Kajian biaya produksi pada usaha peternakan babi. Jurnal Sosek Peternakan Unibraw Malang. Volume 12 No. 1. Malang.

Rahmat, J. 2002. Metode Penelitian Komunikasi. Remaja Rosdakarya. Bandung.

Rasyaf M. 1994. Manajemen Peternakan Ayam Kampung. Penerbit Kanisius. Yogyakarta.

Riady, M. 2004. Tantangan dan Peluang Peningkatan Produksi Sapi Potong Menuju Tahun 2020. Paper pada Lokakarya Nasional Sapi Potong 2004. Dirjen Bina Produksi Peternakan. Jakarta.

Sihombing, D. T. H. 2006. Ilmu Ternak Babi. Ed. 2. Gadjah Mada University Press. Bulaksumur, Yogyakarta 55281.

Simon Pardede, 2015. Analisis Biaya dan Keuntungan Usaha Peternakan Babi Rakyat di Desa Cigugur, Kecamatan Cigugur Kabupaten Kuningan Jawa Barat. Skripsi. Fakultas Peternakan Universitas Padjadjaran-Bandung.

Soekartawi, 2003. Teori Ekonomi Produksi Dengan Pokok Bahasan Analisis Fungsi Cobb-Douglas. Cetakan ke-3. PT. Raja Grafindo Persada. Jakarta.

Steel., G.D., and J.H. Torrie. 1980. Prinsip dan Prosedur Statistika (terjemahan). Pt. Gramedia Pustaka Utama. Jakarta.

Yusdja, Y., H. Malian., B. Winarso, Sayuti dan A.S. Bagyo. 2001. Analisa kebijakan pengembangan agribisnis komoditas unggulan peternakan. Pusat Penelitian dan Pengembangan Sosial Ekonomi Pertanian. Badan Litbang Pertanian-Bogor.

Zadrak M. Warouw, V. V. J. Panelewen dan Arie Dp. Mirah. 2014. Analisis usaha peternakan babi pada perusahaan "Kaswean" Kakaskasen II Kota Tomohon. Jurnal Zootek (“Zootrek” Journal) Vol 34 No. 1:92-102. 